\title{
Coronapandemiens indflydelse på universitetsadjunkters holdning til teknologi i undervisningen
}

Mikkel Godsk, Aarhus Universitet

\begin{abstract}
Artiklen undersøger universitetsadjunkter og postdocs inden for det teknisk-naturvidenskabelige områdes ændrede holdning til teknologi i undervisningen, der er med sandsynlighed kan tilskrives coronapandemien. Ved hjælp af en multivariatanalyse baseret på fire enslydende spørgeskemaundersøgelser blandt samtlige teknisk-naturvidenskabelige deltagerne $(\mathrm{N}=66)$ i Aarhus Universitets adjunktpædagogikum umiddelbart ét år før og ét år efter pandemiens udbrud, identificeres der fire temaer af signifikante ændringer i deltagernes holdning til teknologi i undervisningen. Undersøgelsen viser en generelt og signifikant øget, positiv holdning til teknologi i undervisningen og interesse i de elementer, der omhandler pædagogiske metoder og modeller, teknologiens potentiale og rolle samt brugen af videokonference og video. Endvidere er der en signifikant øget interesse i vidensdeling med kolleger og pædagogisk support. Ingen negative holdningsændringer blev identificeret. Undersøgelsen peger således på et stort aktuelt potentiale for undervisningsudvikling og pædagogisk kompetenceudvikling $\mathrm{i}$ brug af teknologi på universiteterne, da de holdningsmæssige barrierer blandt undervisere, der før blev anset for vanskelige at overkomme, måske er ved at nedbrydes.
\end{abstract}

\section{Engelsk abstract}

The article investigates university science assistant professors and postdocs change of attitude towards technology in teaching and learning that is most likely attributed to the Covid-19 pandemic. Using a multivariate analysis based on identical surveys pre and post the outbreak among all assistant professors and postdocs enrolled in the required teacher professional development programme $(\mathrm{N}=66)$ at Aarhus University, four statistically significant themes of change of attitude towards educational technology are identified. The changes are: an increased interest in pedagogical methods and models for technology in teaching and learning, an increased interest in the educational potential and role of the technology, an increased interest in video conference and video, and an increased interest in knowledge sharing and pedagogical support on technology. No adverse changes are identified. Consequently, the investigation identifies a considerable topical potential to overcome the difficult barriers associated with educators' attitudes towards technology in teaching and learning and the potential for educational and professional development on educational technology. 


\section{Coronapandemiens indflydelse på uddannelse og undervisere}

Coronapandemiens indflydelse på de videregående uddannelser på den lange bane er endnu uvis og den hidtidige forskning og undersøgelser er præget at det begrænsede og aktuelle kendskab man har til dens pædagogiske, tekniske, sundhedsmæssige, økonomiske og organisatoriske følger på de pågældende undersøgelsers tidspunkt. Indtil nu har mange af disse undersøgelser vist sig politiserende og af begrænset værdi, da pandemiens effekt på økonomien, universiteternes organisering samt undervisernes holdning ikke nødvendigvis er som først antaget. Eksempelvis peger tidsskriftet Nature i juni 2020 på, at universiteterne kan være nødt til at gentænke og effektivisere deres undervisningspraksis pga. økonomisk nedtur efter pandemien (som blev til en optur i efteråret 2020) (Witze, 2020). Anderson (2020), Houlden og Veletsianos (2020), Trust og Maloy (2021) samt Hodges et al. (2020) peger på et behov for helt nye organisatoriske processer og pædagogiske modeller for hurtig omlægning af uddannelser og kompetenceudvikling af undervisere, således alle undervisere fremover kan afholde online, synkron nød-undervisning (også omtalt "emergency remote teaching", ERT). Og ifølge Ferdig og Pytash (2021) indebærer pandemien også, at undervisere skal kunne håndtere sociale og følelsesmæssige udfordringer samt konflikter blandt de studerende, der opstår som følge af hjemmeundervisningen. Hodges et al. (2020) peger i den forbindelse på risikoen for, at undervisernes aktuelle erfaringer med ERT kan stigmatisere al online undervisning som værende af lavere kvalitet end tilstedeværelsesundervisning. Det er således fristende at drage den konklusion, at undervisernes erfaring og holdning til ERT også er gældende for online ikke-ERT, og universiteterne derfor står med øgede pædagogiske udfordringer $\mathrm{i}$ forbindelse med kvalificeret anvendelse af teknologi $\mathrm{i}$ undervisningen. Men denne konklusion forudsætter, at underviserne ikke kender forskel på ERT og veltilrettelagt online undervisning på trods af fx kompetenceudviklingstiltag o lign.

\section{Undervisernes holdning og dens betydning}

En undersøgelse fra omlægningen på AU i foråret 2020 viste, at godt halvdelen af underviserne (47\%) ikke følte sig pædagogisk klædt på til omlægningen, og at de dertil oplevede en række kommunikative, praktiske og sociale begrænsninger ved det online format (Rambøll, 2020). Det er i den forbindelse vigtigt at bemærke, at der i praksis tales om ERT, da "omlægningen" og "online læring” refererer til "online undervisning siden nedlukningen af universitetet den 12. marts 2020" (Rambøll, 2020, s. 9) og indtil spørgeskemaundersøgelsen blev lukket i juni-juli 2020. Rambølls undersøgelse siger derfor ikke noget præcist om undervisernes generelle holdning til teknologi i undervisningen, men den indikerer en bred erkendelse af, at selv ERT har et pædagogisk aspekt. Dertil kommer, at størstedelen af underviserne udtrykker en positiv holdning over for online undervisning og teknologi i undervisningen. $64 \%$ af underviserne svarer, at de har "făet mere lyst til at finde ud af, hvordan [de] gennemfører online undervisning af høj kvalitet", og $56 \%$ svarer, at de er "blevet mere motiveret for at udvikle [deres] fysiske undervisning med brug af digitale værktøjer" (Rambøll, 2020, s. 31).

Med andre ord ser det ud til, at coronapandemien har en indflydelse på undervisernes holdning til teknologi i undervisningen, som kan påvirke kommende undervisning og dertilhørende pædagogiske behov. Det er imidlertid vanskeligt at planlægge nye pædagogiske tiltag på baggrund af Rambølls undersøgelse og de føromtalte artikler pga. deres fokus på ERT og eventuelle politiserende karakter. Hvis man vil blive klogere på det reelle billede og de implikationer coronapandemien og ERT måtte have for undervisningsudviklingen fremadrettet, er det nødvendigt at undersøge undervisernes holdning og holdningsændring til teknologi i undervisningen i bredere forstand. Dertil kommer, at netop undervisernes interesse i og holdningen til teknologi i undervisningen identificeres i litteraturen som en væsentlig barriere for vellykket ibrugtagning (Ertmer, 1999). Ifølge Ertmer (1999) er det ikke tilstrækkeligt at sikre adgang til den rette teknologi, tid til planlægning af undervisningen samt teknisk og administrativ support. Det er også nødvendigt at overvinde de såkaldte andenordensbarrierer. 
Andenordensbarrierer beskrives som underviser-intrinsic, dvs. barrierer, der relaterer sig til undervisernes opfattelse af undervisning, læring og brug af teknologi i undervisningen. Flere studier peger på, at andenordensbarriererne er vanskeligere at overkomme end tekniske og tidsmæssige barrierer pga. deres rodfæste i undervisernes holdning til undervisning (med teknologi) og det faktum, at denne holdning ikke er umiddelbar synlig (Ertmer, 1999 med reference til Brickner, 1995; Dede, 1998; Fisher et al., 1996). Også i det lys er det interessant at kende til undervisernes holdning til teknologi i undervisningen, da det kan give en indikation af omfanget af de andenordensbarrierer, universiteterne står overfor. Eksempelvis, om universiteterne er bedre eller ringere stillet ift. brug af teknologi i undervisningen end før pandemiens udbrud samt hvordan kommende pædagogiske og teknologiske undervisningsudviklingsindsatser kan tilrettelægges efter undervisernes behov. Nærværende artikel søger at afdække den holdning blandt universitetsadjunkters og postdocs og derigennem klarlægge det pædagogiske udviklingspotentiale på dette område vha. følgende undersøgelsesspørgsmål:

* Hvad er coronapandemiens indflydelse på teknisk-naturvidenskabelige universitetsadjunkter og postdocs holdning til teknologi i undervisningen?

Artiklen anerkender i den forbindelse, at holdningsbegrebet er flertydigt, ligesom man ikke med sikkerhed ville kunne tilskrive en holdningsændring til coronapandemien isoleret set. Holdningsbegrebet er derfor adresseret vha. fire forskellige indikatorer, der tilsammen udtrykker en række vigtige aspekter (se afsnittet "Metode og datagrundlag"). Endvidere er de statistiske sandsynligheder beregnet for indikatorerne, således der kan tales om pandemiens sandsynlige indflydelse.

\section{Adjunktpædagogikum ved Aarhus Universitet}

En central og grundlæggende komponent i kompetenceudviklingen af undervisere ved Aarhus Universitet (AU) er Adjunktpædagogikum og dets modul om teknologi i undervisningen. Modulet om teknologi i undervisningen er tilrettelagt forskelligt for universitetets fakulteter, men for de teknisknaturvidenskabelige adjunkters og postdocs vedkommende har det siden 2012 været benævnt "Digital Learning Design" og tilrettelagt som et fleksibelt, online modul á ca. 25 timers arbejdsindsats (1 ECTS) fordelt på ca. fire uger. Temaet for modulet er digital læringsteknologi (her også omtalt "teknologi"), blended og online læring samt Learning Design. Læringsmålene består i at introducere til relevante, digitale læringsteknologier og dertilhørende pædagogiske metoder samt at give deltagerne evnen til at vurdere, anvende og udvikle undervisning med digital læringsteknologi samt blended og online undervisning vha. Learning Design-metodologien. Learning Design-metodologien og dens seks iboende karakteristika, dvs. (1) inddragelse og operationalisering af pædagogisk teori vha. pædagogiske modeller, teorier o lign., (2) undervisere som aktive, reflekterede designere, (3) studentercentreret undervisning og læring, (4) en designproces støttet af relevante redskaber, (5) fokus på bæredygtighed i form af genbrug og deling af designs samt (6) inkorporering af teknologi i undervisningen (Dalziel et al., 2016; Dohn et al., 2019), spiller således en central rolle på modulet og præsenteres som kerneværdier (se Figur 1).

Modulet består af 3 undervisningsuger med hver sin dertilhørende læringssti i Blackboard (Figur 1). Hver læringssti består af 10-15 trin (36 i alt, 34 i februar 2021 pga. en fletning af emnet om peer instruction) bestående af tekster, der kæder materialer og aktiviteter sammen, artikler, video og 4-8 asynkrone aktiviteter af forskellig varighed. Læringsstierne er suppleret af $i$ alt 2 synkrone aktiviteter af en times varighed i Adobe Connect eller Zoom, der hhv. introducerer til videokonference som undervisningsformat samt faciliterer en afsluttende peer feedbackrunde. Størstedelen af de asynkrone aktiviteter er tilrettelagt som diskussioner med peer feedback i Blackboard. Endvidere er enkelte aktiviteter tilrettelagt i Blackboards wiki- og quizværktøj samt i begrænset omfang vha. eksterne teknologier såsom Mentimeter, 360-video og virtuelle laboratorier. 


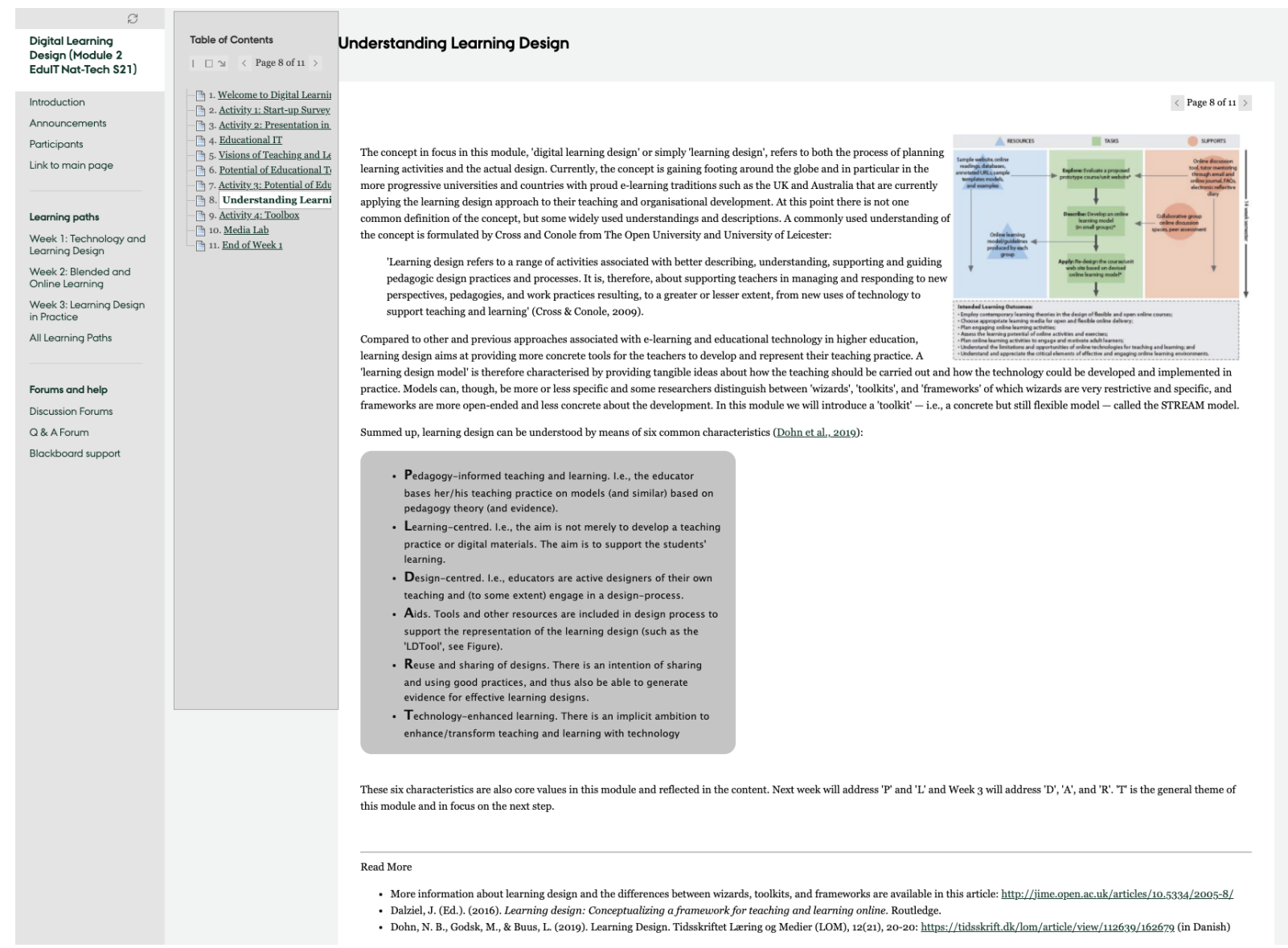

Figur 1. Screenshot af modulets trin 8 om Learning Design i læringsstien "Week 1: Technology and Learning Design".

Modulet afholdes halvårligt, i hhv. september og februar, og er en obligatorisk del af universitetets adjunktpædagogikum der, som udgangspunkt, er en forudsætning for at opnå fastansættelse. Næsten alle adjunkter og postdocs fra det teknisk-naturvidenskabelige område med ambitioner om en videre karriere på universitetet deltager således i modulet. Vinterafholdelsen er for dansktalende adjunkter og postdocs, mens afholdelsen i september er for såvel dansktalende som internationale adjunkter og postdocs ved AU.

Siden 2018, har hverken modulets form, indhold eller evaluering ændret sig med undtagelse af fire mindre justeringer: en figur af STREAM-modellen blev erstattet af en video-introduktion (september 2020), Adobe Connect er erstattet af Zoom som videokonferenceteknologi (september 2020), tre mindre trin om peer instruction er flettet til ét trin og PeerWise udgik (februar 2021), og der blev tilføjet en ny fremtidsvisionsvideo til de eksisterende to videoer (februar 2021). Omfangsmæssigt påvirker justeringerne ca. 10-15\% af deltagernes aktivitet på modulet i større eller mindre omfang. Det er således højst usandsynligt, at justeringerne kan forklare den generelle holdningsændring (se detaljer senere).

\section{Metode og datagrundlag}

I denne artikel indgår resultaterne fra spørgeskemaundersøgelsen ved de seneste fire afholdelser af modulet: to afholdelser før pandemiens udbrud i Danmark i hhv. september 2019 og februar 2020, samt de to efterfølgende afholdelser i hhv. september 2020 og februar 2021. I alt 66 adjunkter og postdocs gennemførte modulet $(\mathrm{N}=66)$ : 31 før pandemiens udbrud, 35 efter, og svarprocenten er $100 \%$. Med undtagelse af de førnævnte justeringer, blev der hverken ændret i modulets form eller indhold i denne 
periode, ligesom deltagernes gennemsnitlige, tidsmæssige indsats var sammenlignelig, hvad enten man kigger på deres selvrapporterede tidsforbrug (se Tabel 1) eller statistikken fra Blackboard (27 timer før, 25 timer efter). Ligeledes var holdenes størrelse og sammensætning sammenlignelig.

Datagrundlaget for undersøgelsen er fire holdningsrelaterede indikatorer fra modulets omfattende evaluering af deltagernes oplevede læringsudbytte, vurderet relevans, holdning til teknologi i undervisningen og faktorer for ibrugtagning samt tidsforbrug. Selve evalueringen var tilrettelagt som et anonymt, men obligatorisk spørgeskema via SurveyXact. Invitation til spørgeskemaet udsendtes netop som sidste aktivitet var afsluttet og løb én uge frem. Udover spørgsmålet til tidsforbrug bestod spørgeskemaet af tre likert-batterier, der spurgte til graden af læringsmålsopfyldelse og formen på modulet, vurderet potentiale for digital læringsteknologi i undervisningen samt vigtigheden af en række faktorer for ibrugtagning af digital læringsteknologi i undervisningen. Endvidere blev deltagerne bedt om at afkrydse de temaer og undertemaer på modulet, som de fandt relevant ift. egen undervisning. Se spørgsmålsformuleringerne og skalaerne nedenfor:

* Oplevet læringsmålsopfyldelse: "to what extent you agree with the following statements about the module", skala: "strongly disagree" (1), "disagree" (2), "neither agree or disagree" (3), "agree" (4), "strongly agree" (5).

* Relevans for egen undervisning: "which of the following topics are relevant to your own teaching and development of teaching", checkboks.

* Holdning til teknologi i undervisningen og Learning Design: "to what extent you agree with the following statements about educational technology and the learning design approach", skala: "strongly disagree" (1), "disagree" (2), "neither agree or disagree" (3), "agree" (4), "strongly agree" (5).

* Faktorer for ibrugtagning af teknologi og Learning Design: "If you were to adopt a learning design (such as STREAM, Just-in-Time Teaching, the Five Stage Model, a model for structured discussions, etc.) in your teaching, to what extent are the following criteria important to you", skala "to a very high extent" (5), "to a high extent" (4), "to a certain extent" (3), "to a limited extent" (2), "to a very limited extent" (1), "not at all" (o)

Likert-værdierne er omregnet til en skala fra $1-5$ eller $0-5$, hvoraf 5 er højest og 3 repræsenterer en neutral/moderat værdi (se listen ovenfor). "Not applicable/don't know" er frasorteret. Værdierne er suppleret af et gennemsnit og, hvis relevant, en standardafvigelse (SD), mens checkboks-svarene er omregnet til procenter (Tabel 1). Dertil kommer den data, der indsamles om deres tidsforbrug på modulet. Hvert af disse temaer og undertemaer er repræsenteret som ét eller flere afgrænsede indholdselementer i læringsstierne, hvilket gør det muligt at kæde deltagernes vurderinger sammen med det konkrete indhold. Som supplement til procentsatserne, er der lavet en multivariatanalyse baseret på Pearson (r) i SPSS, der sammenligner adjunkternes holdninger før og efter coronaudbruddet for statistisk signifikante korrelationer (Tabel 1). Hensigten med multivariatanalysen er at identificere statistisk signifikante holdningsændringer til teknologi i undervisningen, som med sandsynlighed kan tilskrives pandemien. Statistiske signifikante korrelationer er markeret med * eller ** i Tabel 1 efter signifikans. Eksempelvis udtrykker en korrelationskoefficient på $r=.400^{* *}$ en moderat, positiv og statistisk signifikant sammenhæng mellem det pågældende udsagn og tidspunktet for pandemiens udbrud. Eller, sagt med andre ord, at den vurderede læringsmålsopfyldelse, relevans eller holdning til det pågældende emne er signifikant øget efter pandemiens udbrud. Asterisken markerer den statistiske signifikans, hvor * udtrykker en $95 \%$ sikkerhed på en sammenhæng mellem udsagnet og pandemiens udbrud, og ** udtrykker 99\% sikkerhed på en sammenhæng. Korrelationskoefficienter, der ikke er markeret med asterisk er mindre end 95\% sikre og kan dermed ikke betegnes som statistisk signifikante. 
De statistisk signifikante korrelationer er efterfølgende grupperet i temaer, hvorefter temaerne er yderligere begrundet af de indholdselementer eller andre omstændigheder ved modulet, som udsagnene henviser til.

\section{Resultater}

På tværs af de fire spørgeskemaundersøgelser kan der identificeres otte statistisk signifikante ændringer, når man sammenligner afholdelserne før og efter coronaudbruddet (se asteriskmarkeringerne i Tabel 1). Én ændring er relateret til oplevet læringsmålsopfyldelse, fire er relateret til oplevet relevans af emnerne ift. egen undervisning, to er relateret til adjunkternes generelle holdning til teknologi og Learning Design i undervisningen og én er relateret til faktorer for deres ibrugtagning af teknologi og Learning Design i undervisningen. Samlet set grupperer de signifikante korrelationer sig i fire temaer, som er uddybet i de følgende afsnit: (1) øget interesse i pædagogiske metoder og modeller, (2) øget interesse i viden om teknologiens potentiale og rolle, (3) øget interesse i videokonference og video samt (4) øget interesse i vidensdeling og pædagogiske support.

Tabel 1. Samlet oversigt over ændret tidsforbrug og holdningsændring udtrykt vha. oplevet læringsmålsopfyldelse, relevans, holdning til teknologi i undervisningen og faktorer for ibrugtagning før og efter pandemiens udbrud samt den statistiske signifikans.

\begin{tabular}{|c|c|c|c|c|}
\hline \multirow{2}{*}{ Holdningsindikatorer } & \multirow{2}{*}{\multicolumn{2}{|c|}{$\frac{\text { Statistisk signifikans }}{\text { Endring fra før til efter }}$}} & \multicolumn{2}{|c|}{ Gennemsnit (SD) } \\
\hline & & & \multirow[t]{2}{*}{ Før } & \multirow[t]{2}{*}{ Efter } \\
\hline \multicolumn{3}{|l|}{ Tidsforbrug (i timer) } & & \\
\hline \multirow[t]{2}{*}{ How many hours have you spent on the module? } & Pearson Correlation & -.085 & $27,4(14,1)$ & $25,1(13,1)$ \\
\hline & Sig. (2-tailed) & .495 & & \\
\hline \multicolumn{5}{|l|}{ Oplevet læringsmålsopfyldelse } \\
\hline \multirow{2}{*}{$\begin{array}{l}\text { Overall, the module has given me insight into relevant } \\
\text { educational technologies as well as related pedagogical } \\
\text { methods and theories }\end{array}$} & Pearson Correlation & .150 & $4,0(0,8)$ & $4,2(0,7)$ \\
\hline & Sig. (2-tailed) & .230 & & \\
\hline \multirow{2}{*}{$\begin{array}{l}\text { The module has enabled me to evaluate the potential } \\
\text { of using educational technology in teaching practice }\end{array}$} & Pearson Correlation & .095 & $3,9(0,7)$ & $4,0(0,9)$ \\
\hline & Sig. (2-tailed) & .446 & & \\
\hline \multirow{2}{*}{$\begin{array}{l}\text { The module has enabled me to transform traditional } \\
\text { teaching into blended and online teaching }\end{array}$} & Pearson Correlation & $.259^{*}$ & $3,5(0,9)$ & $3,9(0,8)$ \\
\hline & Sig. (2-tailed) & .036 & & \\
\hline \multirow{2}{*}{$\begin{array}{l}\text { The module has enabled me to design and develop } \\
\text { technology-enhanced, blended, and online learning }\end{array}$} & Pearson Correlation & .143 & $3,7(0,7)$ & $3,9(0,7)$ \\
\hline & Sig. (2-tailed) & .253 & & \\
\hline \multirow{2}{*}{$\begin{array}{l}\text { The module has enabled me to teach with educational } \\
\text { technology }\end{array}$} & Pearson Correlation & .115 & $3,5(0,9)$ & $3,7(0,9)$ \\
\hline & Sig. (2-tailed) & .358 & & \\
\hline \multicolumn{5}{|c|}{ Relevans for egen undervisning og undervisningsudvikling } \\
\hline \multirow{2}{*}{$\begin{array}{l}\text { The potential of educational technology and } \\
\text { educational IT }\end{array}$} & Pearson Correlation & $.286^{*}$ & $65 \%$ & $89 \%$ \\
\hline & Sig. (2-tailed) & .020 & & \\
\hline \multirow{2}{*}{$\begin{array}{l}\text { The technological toolbox (i.e., the overview of } \\
\text { technologies supported...) }\end{array}$} & Pearson Correlation & .070 & $71 \%$ & $77 \%$ \\
\hline & Sig. (2-tailed) & .574 & & \\
\hline \multirow[t]{2}{*}{ The SAMR model } & Pearson Correlation & $.270^{*}$ & $23 \%$ & $49 \%$ \\
\hline & Sig. (2-tailed) & .029 & & \\
\hline \multirow{2}{*}{$\begin{array}{l}\text { Technology and pedagogy (i.e., Conole's pedagogy } \\
\text { framework for mapping tools-in-use) }\end{array}$} & Pearson Correlation & .160 & $35 \%$ & $51 \%$ \\
\hline & Sig. (2-tailed) & .198 & & \\
\hline \multirow[t]{2}{*}{ The STREAM model } & Pearson Correlation & $.400^{* * *}$ & $48 \%$ & $86 \%$ \\
\hline & Sig. (2-tailed) & .001 & & \\
\hline \multirow{2}{*}{$\begin{array}{l}\text { Video in science teaching (i.e., lecture capturing, } \\
\text { webcasts, lab videos) }\end{array}$} & Pearson Correlation & .231 & $74 \%$ & $91 \%$ \\
\hline & Sig. (2-tailed) & .062 & & \\
\hline \multirow[t]{2}{*}{ The flipped classroom } & Pearson Correlation & .209 & $65 \%$ & $83 \%$ \\
\hline & Sig. (2-tailed) & .092 & & \\
\hline \multirow[t]{2}{*}{ Peer Instruction ${ }^{* * * *}$} & Pearson Correlation & .120 & $55 \%$ & $67 \%$ \\
\hline & Sig. (2-tailed) & .384 & & \\
\hline \multirow[t]{2}{*}{ Mentimeter } & Pearson Correlation & .069 & $74 \%$ & $80 \%$ \\
\hline & Sig. (2-tailed) & .581 & & \\
\hline E-tivities/the 5-stage model for online learning & Pearson Correlation & .084 & $52 \%$ & $60 \%$ \\
\hline
\end{tabular}




\begin{tabular}{|c|c|c|c|c|}
\hline & Sig. (2-tailed) & .501 & & \\
\hline \multirow[t]{2}{*}{ Structured online discussions } & Pearson Correlation & .156 & $39 \%$ & $54 \%$ \\
\hline & Sig. (2-tailed) & .212 & & \\
\hline \multirow[t]{2}{*}{ Virtual laboratories } & Pearson Correlation & -.020 & $42 \%$ & $40 \%$ \\
\hline & Sig. (2-tailed) & .876 & & \\
\hline \multirow[t]{2}{*}{ Adobe Connect/Zoom ${ }^{* * * * *}$} & Pearson Correlation & $.331^{* *}$ & $48 \%$ & $80 \%$ \\
\hline & Sig. (2-tailed) & .007 & & \\
\hline \multirow[t]{2}{*}{ The LDTool for representing learning designs } & Pearson Correlation & .075 & $35 \%$ & $43 \%$ \\
\hline & Sig. (2-tailed) & .548 & & \\
\hline \multirow[t]{2}{*}{ VR and 360 video } & Pearson Correlation & .158 & $23 \%$ & $37 \%$ \\
\hline & Sig. (2-tailed) & .205 & & \\
\hline \multirow[t]{2}{*}{ Mobile learning } & Pearson Correlation & .080 & $32 \%$ & $40 \%$ \\
\hline & Sig. (2-tailed) & .521 & & \\
\hline \multicolumn{5}{|c|}{ Holdning til teknologi i undervisningen og Learning Design } \\
\hline \multirow{2}{*}{$\begin{array}{l}\text { I see a potential for Educational Technology in } \\
\text { sciences and engineering (Nat-Tech) education }\end{array}$} & Pearson Correlation & .234 & $4,2(0,7)$ & $4,5(0,6)$ \\
\hline & Sig. (2-tailed) & .059 & & \\
\hline \multirow{2}{*}{$\begin{array}{l}\text { I see a potential for Learning Design in sciences and } \\
\text { engineering (Nat-Tech) education }\end{array}$} & Pearson Correlation & $.386^{* * *}$ & $3,8(0,9)$ & $4,4(0,6)$ \\
\hline & Sig. (2-tailed) & .001 & & \\
\hline \multirow{2}{*}{$\begin{array}{l}\text { I consider it to be easy to use Learning Design in my } \\
\text { own teaching practice ****** }\end{array}$} & Pearson Correlation & $.273^{*}$ & $3,5(0,7)$ & $3,9(0,9)$ \\
\hline & Sig. (2-tailed) & .028 & & \\
\hline \multicolumn{5}{|c|}{ Vigtige faktorer for ibrugtagning af Learning Design (teknologi i undervisningen) } \\
\hline \multirow{2}{*}{$\begin{array}{l}\text { Access to a knowledge exchange and networking group } \\
\text { with peers }\end{array}$} & Pearson Correlation & $.250^{*}$ & $2,8(1,2)$ & $3,3(0,9)$ \\
\hline & Sig. (2-tailed) & .043 & & \\
\hline \multirow[t]{2}{*}{ Easy access to educational and pedagogical support } & Pearson Correlation & .206 & $3,4(1,2)$ & $3,9(1,0)$ \\
\hline & Sig. (2-tailed) & .096 & & \\
\hline
\end{tabular}

* Correlation is significant at the 0.05 level (2-tailed). ${ }^{* *}$ Correlation is significant at the o.01 level (2tailed). ${ }^{* *} \mathrm{~N}=55$ pga. en ændring af denne aktivitet i februar 2021. ${ }^{* * *} \mathrm{~N}=65$ pga. et "don't know"svar i februar 2020. ${ }^{* * * *}$ Adobe Connect blev erstattet af Zoom som videokonferenceteknologi september 2020.

\section{Øget interesse i pædagogiske metoder og modeller}

Korrelationerne viser en signifikant øget interesse i pædagogiske metoder og modeller til tilrettelæggelse af undervisning med teknologi. Dette kommer til udtryk i den øgede vurderede relevans af STREAMmodellen $\left(r=.400^{* *}\right)$ (se Godsk, 2013), som er én af de seks Learning Design-modeller og pædagogiske metoder kurset introducerer. Dertil kommer en øget positiv holdning til Learning Design i teknisknaturvidenskabelig undervisning $\left(r=.386^{* *}\right)$ samt at det vurderes som lettere at bruge Learning Design i egen praksis $\left(r=.273^{*}\right)$. Før udbruddet fandt $48 \%$ STREAM-modellen relevant for egen undervisning. Denne andel er steget til 86\% efter udbruddet. Endvidere er der en øget positiv, men ikke signifikant, interesse i de øvrige pædagogiske modeller og metoder, herunder flipped classroom $(r=.209)$, strukturerede online diskussioner $(r=.156)$, peer instruction $(r=.120)$ og e-tivities/the 5 -stage model $(r=.084)$ (Salmon, 2012) (Tabel 1). Særligt STREAM indgår i flere trin og aktiviteter pga. dens relevans for fagområdet og dens forhistorie på AU (se Bjælde et al., 2015). Ift. STREAM kan forklaringen også delvis relatere sig til formidlingen. Hvor STREAM før coronaudbruddet blev formidlet vha. artikler, tekster, figur, eksempler og aktivitet, blev figuren efterfølgende erstattet af en 5-minutters-video, der forklarer modellens funktion og anvendelse i praksis. Statistikken for videoen viser dog, at maksimalt halvdelen har set videoen til ende. Det er således usandsynligt, at denne video alene forklarer den øgede interesse i de pædagogiske metoder og modeller. Den øvrige formidling af STREAM, flipped classroom, de øvrige modeller og metoder samt Learning Design er uændret. Det er således sandsynligt, at holdningsændringen skyldes en ny interesse og/eller behov for pædagogiske metoder og modeller. 


\section{$\varnothing$ get interesse i viden om teknologiens potentiale og rolle}

Korrelationerne viser en øget interesse i viden om teknologiens potentialer samt modeller til at forstå dens rolle. Endvidere opleves modulet som mere givende ift. omlægning af undervisningen til blended og online læring. Dette kommer til udtryk i interessen for de indholdselementer, der omhandler metoder og modeller til at forstå teknologiens rolle og pædagogiske potentialer, herunder elementet om SAMRmodellen $\left(r=.270^{*}\right)$ (Puentedura, 2010, se også Godsk, 2014), om Conoles model for at analysere teknologiens pædagogiske brug $(r=.205)$ (Conole et al., 2004) og emnet om teknologiens potentialer i undervisningen $\left(r=.286^{*}\right)$. Emnet om teknologiens potentialer bliver adresseret vha. tekst, $2-3$ valgfri videoer om fremtidens undervisning med teknologi, Price og Kirkwoods (2011) oversigt over teknologiens potentialer samt en dertilhørende diskussion. Før udbruddet fandt $65 \%$ emnet om teknologiens potentialer i undervisningen relevant, mens $89 \%$ fandt det relevant efter udbruddet. Dertil kommer en øget oplevelse af, at modulet har klædt dem på til at transformere traditionel tilstedeværelsesundervisning til blended og online undervisning $\left(r=.259^{*}\right)$.

\section{$\varnothing$ get interesse i videokonference og video}

Korrelationerne viser også en øget interesse i videokonference og video. Dette kommer til udtryk i en højere vurderet relevans af Zoom efter udbruddet på $80 \%\left(r=.331^{* *}\right)$ i forhold til $48 \%$ vurderet relevans af Adobe Connect før udbruddet. Det er den forbindelse vigtigt at bemærke, at Adobe Connect blev erstattet af Zoom som videokonferenceteknologi i to aktiviteter samtidig med pandemiens udbrud, men at den pædagogiske introduktion er sammenlignelig. Forklaringen i den øgede interesse i videokonference kan således både skyldes pandemien og skift af teknologi. Foruden videokonference er der også en øget interesse i asynkron video, herunder lecture capturing, videostudieoptagelser og laboratorievideoer i undervisningen $(r=.231)$. 91\% finder nu dette emne relevant for deres undervisning og undervisningsudvikling mod 74\% før udbruddet. Den øgede interesse i teknologien er forventet i lyset af behovet for at afholde undervisning via video, men det er igen værd at bemærke, at teknologierne præsenteres med en pædagogisk ramme. Der introduceres primært til teknologiernes potentialer, relevante pædagogiske modeller samt potentiel effekt på undervisningen, men sjældent $\mathrm{i}$ teknologiens konkrete funktionalitet og praktiske anvendelse.

\section{Øget interesse i vidensdeling og pædagogisk support}

Undersøgelsen peger også på en signifikant øget interesse i vidensdeling og adgang til vidensdelings- og netværksgruppe blandt undervisere $\left(r=.250^{*}\right)$ samt interesse i let adgang til pædagogisk support $(r=$ .206) ved ibrugtagning af teknologi vha. Learning Design-modeller. Hele $75 \%-91 \%$ af underviserne finder nu adgang til dette vigtigt for ibrugtagning. Tallene tyder således på en større interesse for samarbejde og en mulig erkendelse af, at ibrugtagning af teknologi kræver pædagogisk knowhow.

\section{Ingen negative holdningsændringer}

Ingen af korrelationerne peger på en signifikant negativ holdningsændring til hverken teknologi i undervisningen eller Learning Design. Dertil kommer, at den vurderede relevans af de adresserede teknologier, pædagogiske emner og oplevet læringsmålsopfyldelse er øget. Det er ikke overraskende, at praktisk viden om teknologierne til ERT opleves som mere relevant, men det var ikke givet, at pædagogiske emner ville blive oplevet lige så eller mere relevante end før pandemien. Man kunne eksempelvis have forestillet sig, at deltagerne kun var interesseret i de mest nødvendige, digitale kompetencer til at støtte den påkrævede fjernundervisning. Dette er ikke tilfældet, og det ser i stedet ud til, at pandemien har gjort interessen for pædagogisk kvalificeret anvendelse af teknologi og de dertilhørende metoder større. Teknologien ses altså ikke kun som et quickfix til ERT blandt deltagerne. 


\section{Diskussion}

Artiklen dokumenterer en statistisk signifikant positiv holdningsændring til teknologi i undervisningen blandt teknisk-naturvidenskabelige adjunkter og postdocs, der med sandsynlighed kan tilskrives coronapandemien. Holdningsændringen består i øget interesse i pædagogiske metoder og modeller, øget interesse i viden om teknologiens potentiale og rolle, øget interesse i videokonference og video samt øget interesse i vidensdeling og pædagogiske support. Dertil kommer, at der ikke er identificeret negative holdningsændringer. Undersøgelsen bidrager således med en nuancering af den eksisterende forskning i underviseres holdning til online undervisning som følge af udbruddet. Artiklen peger på, at der ikke er belæg for at tro, at erfaringerne med ERT stigmatiserer online undervisning blandt de teknisk-naturvidenskabelige adjunkter og postdocs - snarere tværtimod - og det ser ud til, at den positive holdningsændring også gør sig gældende for tidligere deltagere. Eksempelvis udtrykker en tidligere deltager en tilsvarende, positiv holdningsændring i dagspressen fra standpunktet: "det bedste er klassisk tilstedeværelsesundervisning" til "jeg vil helt sikkert blive ved med at bruge det [online undervisning]. Flere af mine kolleger har også gjort den oplevelse. At der er elementer i deres kursus, som de vil blive ved med at bruge i deres undervisning fremadrettet, fordi det giver mening rent pædagogisk" (Christensen, 2021).

Den øgede interesse over for de pædagogiske aspekter af teknologi i undervisningen blandt undervisere påpeger også en potentiel større lydhørhed for de bagvedliggende pædagogiske rationaler og teorier, herunder metoder og modeller til design af undervisningen. Denne ændring er især vigtig for at overvinde de udfordrende andenordensbarrierer relateret til undervisernes holdning til teknologi i undervisningen, Ertmer (1999) peger på. Dertil kommer undervisernes interesse i Learning Design, som ligeledes identificeres som en mulig (tredjeordens)barriere eller driver for vellykket teknologibrug (Tsai \& Chai, 2012). Undersøgelsen peger derfor på et stort, aktuelt potentiale for kompetenceudvikling for vellykket anvendelse af teknologi i undervisningen, da holdningen nu er gunstig til at overvinde to niveauer af udbredte barrierer. Et potentiale, som måske ikke - nogensinde - har været større og en unik mulighed for at "return to a better normal", som Ferdig og Pytash (2021) udtrykker det.

Undersøgelsen i denne artikel er overvejende kvantitativ, hvilket har gjort det muligt at identificere statistisk signifikante holdningsændringer og tematisere disse. Metoden giver imidlertid kun begrænset indsigt i holdningsændringernes underliggende årsag, så kommende forskning kunne med fordel undersøge de fire temaer kvalitativt for hvorfor underviserne har fået en øget interesse i det pædagogiske aspekt af digital læringsteknologi og de specifikke teknologier, samt hvorledes kommende kompetence- og undervisningsudvikling skal tilrettelægges for at overvinde de førnævnte barrierer.

\section{Konklusion}

Artiklen dokumenterer en statistisk signifikant positiv holdningsændring til teknologi og pædagogisk kvalificeret brug heraf i undervisningen på fire vigtige områder på basis af i alt fire spørgeskemaundersøgelser blandt samtlige teknisk-naturvidenskabelige adjunkter og postdocs i forbindelse med Adjunktpædagogikum på Aarhus Universitet et år før og et år efter coronapandemiens udbrud. Med forbehold for den begrænsede effekt justeringerne på modulet kan have medført, kan holdningsændringen med stor sandsynlighed tilskrives coronapandemien og de vilkår, den har forårsaget. Endvidere peger artiklen på et stort aktuelt potentiale for at overvinde de holdnings- og designproces-barrierer blandt underviserne for vellykket anvendelse af teknologi i undervisningen. Et potentiale som med fordel kan danne grundlag for udviklingen af kommende kompetenceudviklingstilbud til undervisere og andre undervisningsudviklingsinitiativer. 


\section{Referencer}

Bjælde, O. E., Caspersen, M. E., Godsk, M., Hougaard, R. F., \& Lindberg, A. B. (2015). Learning design for science teacher training and educational development. Globally connected, digitally enabled. Proceedings ascilite 2015 .

Brickner, D. L. (1995). The effects of first and second-order barriers to change on the degree and nature of computer usage of mathematics teachers: A case study (Doctoral dissertation, Purdue University).

Christensen, C. (2021). 'Vi vender ikke tilbage til det, vi havde før': Universiteter vil beholde dele af onlineundervisningen. DR Nyheder Indland. 19. marts 2021. Hentet fra: https://www.dr.dk/nyheder/indland/vi-vender-ikke-tilbage-til-det-vi-havde-foer-universiteter-vil-beholdedele-af

Conole, G., Dyke, M., Oliver, M., \& Seale, J. (2004). Mapping pedagogy and tools for effective learning design. Computers \& Education, 43(1-2), 17-33.

Dalziel, J., Conole, G., Wills, S., Walker, S., Bennett, S., Dobozy, E., Cameron, L., Badilescu-Buga, E., \& Bower, M. (2016). The Larnaca Declaration on Learning Design-2013. In J. Dalziel (Ed.). Learning design: Conceptualizing a framework for teaching and learning online. Routledge.

Dede, C. (1998). Learning with Technology. 1998 ASCD Yearbook. Association for Supervision and Curriculum Development, 1250 N. Pitt St., Alexandria, VA 22314-1453

Dohn, N. B., Godsk, M., \& Buus, L. (2019). Learning Design. Tidsskriftet Læring og Medier (LOM), 12(21), $20-20$.

Ertmer, P. A. (1999). Addressing first-and second-order barriers to change: Strategies for technology integration. Educational technology research and development, 47(4), 47-61.

Ferdig, R. E., \& Pytash, K. E. (2021). Preface. In Ferdig, R. E., \& Pytash, K. E. (eds.). What Teacher Educators Should Have Learned from 202O. AACE-Association for the Advancement of Computing in Education. Hentet fra: https://learntechlib.org/primary/d/219088/

Fisher, C., Dwyer, D. C., \& Yocam, K. (1996). Education \& Technology: Reflections on Computing in Classrooms. Jossey-Bass Publishers, San Francisco.

Godsk, M. (2013). STREAM: a Flexible Model for Transforming Higher Science Education into Blended and Online Learning. In T. Bastiaens \& G. Marks (Eds.), Proceedings of World Conference on E-Learning in Corporate, Government, Healthcare, and Higher Education 2013 (pp. 722-728). Chesapeake, VA: AACE.

Godsk, M. (2014). Efficient learning design - concept, catalyst, and cases. In B. Hegarty, J. McDonald, \& S.-K. Loke (Eds.), Rhetoric and Reality: Critical perspectives on educational technology. Proceedings ascilite Dunedin 2014 (pp. 182-189). Hentet fra: https://ascilite2014.otago.ac.nz/files/fullpapers/146-Godsk.pdf

Hodges, C., Moore, S., Lockee, B., Trust, T., \& Bond, A. (2020). The difference between emergency remote teaching and online learning. Educause review, 27, 1-12. Hentet fra:

https://er.educause.edu/articles/2020/3/the-difference-between-emergency-remote-teaching-and-onlinelearning

Houlden, S., \& Veletsianos, G. (2020). Coronavirus pushes universities to switch to online classes - But are they ready? The Conversation. Hentet fra: https://theconversation.com/coronavirus-pushes-universities-toswitch-to-online-classes-but-are-they-ready-132728

Price, L., \& Kirkwood, A. (2011). Enhancing professional learning and teaching through technology: a synthesis of evidence-based practice among teachers in higher education. Higher Education Academy, York, UK. Hentet fra: http://oro.open.ac.uk/30686/

Puentedura, R. (2010). SAMR and TPCK: Intro to Advanced Practice. Hentet fra: http://hippasus.com/resources/sweden2010/SAMR_TPCK_IntroToAdvancedPractice.pdf

Salmon, G. (2012). E-moderating: The key to online teaching and learning. Third Edition. New York: Routledge.

Rambøll (2020). Undersøgelse af online undervisning og eksamen forår 2020. Aarhus Universitet rapport. Oktober 202O. Hentet fra: https://newsroom.au.dk/fileadmin/Artikler/AU KommunikationMedier/Kommunikation/Undersoegelse af online undervisning og eksamen foraar 2020 191020.pdf

Trust, T., \& Maloy, R. W. (2021). Foreword. In Ferdig, R. E., \& Pytash, K. E. (eds.). What Teacher Educators Should Have Learned from 202O. AACE-Association for the Advancement of Computing in Education. Hentet fra: https://learntechlib.org/primary/d/219088/

Tsai, C. C., \& Chai, C. S. (2012). The "third"-order barrier for technology-integration instruction: Implications for teacher education. Australasian Journal of Educational Technology, 28(6). Hentet fra: https://ajet.org.au/index.php/AJET/article/view/810

Witze, A. (2020). Universities Will Never Be the Same after the Coronavirus Crisis. Nature 582. 162-164 (2020) doi: https://doi.org/10.1038/d41586-020-01518-y 


\section{Forfatter}

\section{Mikkel Godsk}

Undervisningsudvikler, EdD

Centre for Educational Development, Aarhus Universitet 